Asian J Agric \& Biol. 2022(3).

$\mathrm{AJAB}$

DOI: $10.35495 / a j a b .2021 .03 .138$

Original Article

\title{
Chemical composition and anti-diabetic activities in two novel accessions of Cinnamon (Cinnamomum zeylanicum) leaves grown in Sri Lanka
}

\begin{abstract}
Nimarsha Sonali Kamaradiwela Arachchige, Bimali Jayawardena*
Department of Chemistry, University of Kelaniya, Kelaniya, Sri Lanka

Received:

March 27, 2021

Accepted:

October 26, 2021

Online First:

January 02, 2022

Published:

June 06, 2022

\section{Abstract}

Diabetes Mellitus is a major health concern in many countries. Although there are many synthetic drugs to manage diabetes, most of them are associated with many side effects. Hence there is attention to the use of natural herbs with fewer side effects as an alternative. In this study the hypoglycemic properties, biological activities and chemical composition of leaves of two new Cinnamomum zeylanicum accessions (Sri Wijaya and Sri Gemunu) were investigated using spectrometric techniques. Ethanolic extracts of the two accessions were tested for alpha-amylase inhibitory activity $\left(\mathrm{IC}_{50}\right.$ of Sri Gemunu $0.0565 \pm 0.0013 \mathrm{mg} / \mathrm{mL}, \mathrm{IC}_{50}$ of Sri Wijaya $0.1136 \pm 0.0011 \mathrm{mg} / \mathrm{mL}$ ), alpha-glucosidase inhibitory activity $\left(\mathrm{IC}_{50}\right.$ of Sri Gemunu $0.0347 \pm 0.0002 \mathrm{mg} / \mathrm{mL}$, $\mathrm{IC}_{50}$ of Sri Wijaya $\left.0.0884 \pm 0.0002 \mathrm{mg} / \mathrm{mL}\right)$, total phenolic content $(20.60 \pm 0.01 \mathrm{mg}$ Gallic acid equivalents. $\mathrm{g}^{-1}$ of Sri Gemunu, $6.07 \pm 0.01 \mathrm{mg}$ Gallic acid equivalents. $\mathrm{g}^{-1}$ of Sri Wijaya), total flavonoid content (72.02 $\pm 0.02 \mathrm{mg}$ quercetin equivalents. $\mathrm{g}^{-1}$ of Sri Gemunu, $23.59 \pm 0.02 \mathrm{mg}$ quercetin equivalents. $\mathrm{g}^{-1}$ of Sri Wijaya), total proanthocyanidin content $\left(0.60 \pm 0.05 \mathrm{~g}\right.$ catechin equivalents. $\mathrm{g}^{-1}$ of Sri Gemunu, 0.15 $\pm 0.05 \mathrm{~g}$ catechin equivalents. $\mathrm{g}^{-1}$ of Sri Wijaya) and DPPH radical scavenging activity $\left(\mathrm{IC}_{50}-58.18 \pm 2.53 \mu \mathrm{g} / \mathrm{mL}\right.$ of Sri Wijaya, $\mathrm{IC}_{50}-69.60 \pm 5.48 \mu \mathrm{g} / \mathrm{mL}$ of Sri Gemunu). GC-MS analysis and HPLC analysis indicated that both accessions were rich in eugenol and cinnamaldehyde. According to the results of this study, the ethanolic extract of Sri Gemunu Cinnamomum zeylanicum accession leaves displayed better anti-diabetic properties than the leaves of Sri Wijaya.
\end{abstract}

Keywords: Cinnamomum zeylanicum leaf, Ethanolic extraction, Anti-diabetic, Sri Gemunu accession, Sri Wijaya accession

\section{How to cite this:}

Arachchige NSK and Jayawardena B, 2022. Chemical composition and anti-diabetic activities in two novel accessions of Cinnamon (Cinnamomum zeylanicum) leaves grown in Sri Lanka. Asian J. Agric. Biol. 2022(3): 202103138. DOI: https://doi.org/10.35495/ajab.2021.03.138.

*Corresponding author email: bimali@kln.ac.lk

This is an Open Access article distributed under the terms of the Creative Commons Attribution 3.0 License. (https://creativecommons.org/licenses/by/3.0), which permits unrestricted use, distribution, and reproduction in any medium, provided the original work is properly cited.

\section{Introduction}

Diabetes mellitus (DM) has become an epidemic in the human population. The reason for DM is impaired regulation of carbohydrate metabolism by the hormone insulin. (Kazeem et al., 2013)

Although DM is a metabolic disorder that cannot be cured, it can be managed. The presence of both hydrolytic enzymes $\alpha$-amylase and $\alpha$-glucosidase plays an important role in the digestion of 


\section{Nimarsha Sonali Kamaradiwela Arachchige and Bimali Jayawardena}

carbohydrates in the diet. Diabetic individuals suffer from elevated post-prandial blood sugar levels soon after a meal. To manage this impairment, $\alpha$-amylase and $\alpha$ - glucosidase enzymes inhibitors can be developed as therapeutic agents (Apostolidis and Lee, 2010).

Synthetic drugs have many complications associated with them such as toxicity, potential health risks and costs. Scientists are exploring novel inexpensive and safe treatment methods to control type 2 diabetes (Arachchige et al., 2017).Cinnamomum zeylanicum is an evergreen tropical tree with several medicinal properties (Schmidt et al., 2006). Plant extracts are rich sources of polyphenols and flavonoids. These compounds can impart bioactive beneficial physiological effects. Cinnamon is one of the spices that is considered a therapeutic agent in the treatment of DM (Sangal, 2011). Proanthocyanidins, present in cinnamon are considered as the main bioactive components that exert hypoglycemic effects (Tulini et al., 2016).

Phytochemicals present in Cinnamon are capable of inhibiting $\alpha$-amylase and $\alpha$-glucosidase activities without imparting adverse side effects. Hence these can serve as promising candidates for managing DM (Apostolidis and Lee, 2010).

The aim of this study was to determine the antidiabetic properties in leaves of two new accessions of Ceylon cinnamon; Sri Wijaya and Sri Gemunu introduced by the Cinnamon research station at Palolpitiya, Sri Lanka (Azad et al., 2015).

These two accessions of Cinnamon differ in their morphological characteristics, the chemical composition and quantity of the extracts produced. Sri Gemunu accession bears better bark and leaf oil quality than the Sri Wijaya accession (Liyanage et al., 2017). The Sri Gemunu leaves are oval in shape, medium to large in size with entire margins, and bear a clove-like pleasant odor while Sri Wijaya leaves are lanceolate in shape, small to medium in size with entire margins, and bear a clove-like pleasant odor (Ariyarathne et al., 2018; Fenn and Koppedrayer, 2008).

The phytochemical properties vary in different parts of the plant. In Cinnamon, most studies have focused on the antidiabetic properties of Cinnamomum zeylanicum bark. Studies on the antidiabetic properties of leaves of Cinnamomum zeylanicum are yet to be explored. According to the literature, Cinnamomum zeylanicum leaves are a rich source of antioxidants and antidiabetic activities (Mendis et al.,
2019). Despite of being a rich source of phytochemicals, there are no published data on the antidiabetic activities of these novel leaf accessions. Hence, the anti-diabetic potential of the leaves of new accessions of Cinnamomum zeylanicum was evaluated using in-vitro bioassays and chemical profiling of the extract was performed using GC-MS and HPLC techniques respectively.

\section{Material and Methods}

\section{Chemicals and reagents}

$\alpha$-amylase, $\alpha$-glucosidase, Acarbose, Gallic acid, Catechin, Quercetin, 2,2-diphenyl-2-picrylhydrazyl hydrate (DPPH), Ascorbic acid, Eugenol, Cinnamaldehyde, and Cinnamic acid were purchased from Sigma Aldrich and only analytical grade chemicals and reagents were used.

\section{Collection and preparation of cinnamon leaves}

Fresh leaves of both accessions of Cinnamomum zeylanicum (Sri Gemunu and Sri Wijaya) were collected from cinnamon cultivation at Cinnamon research station, Palolpititya, Sri Lanka. A voucher specimen was placed at the Herbarium collection of the Department of Plant and Molecular Biology, University of Kelaniya, under the Laurel family (Lauraceae) (CIN-SW-001 for "Sri Wijaya" accession and CIN-SG-002 for "Sri Gemunu" accession is the deposition numbers).Cinnamomum zeylanicum leaf accessions were authenticated by a plant taxonomist at the Plant and Molecular Biology Department.

The washed leaves were dried at $50^{\circ} \mathrm{C}$ in an oven overnight to a constant weight. Finally, the leaves were crushed, powdered, and stored at $-20^{\circ} \mathrm{C}$ until used for extraction.

\section{Preparation of ethanolic extracts}

Powdered leaf samples of Sri Gemunu and Sri Wijaya $(10.0 \mathrm{~g})$ were extracted in ethanol $(95 \%$, $200.00 \mathrm{~mL}$ ) for 5-6 $\mathrm{h}$ in a Soxhlet extractor until the extraction was complete. The ethanolic extracts were filtered, evaporated in a rotary evaporator (Rotary evaporator, Buchi B-480, Switzerland) and stored at $-20^{\circ} \mathrm{C}$.

\section{Preparation of water extracts}

Water extracts were prepared using the following two methods.

a. A powdered leaf sample $(10.0 \mathrm{~g})$ was extracted for 


\section{Nimarsha Sonali Kamaradiwela Arachchige and Bimali Jayawardena}

15 minutes using pressurized water $(0.098 \mathrm{MPa})$ $(200.00 \mathrm{~mL})$. The extracts were filtered, concentrated, and stored at $-20^{\circ} \mathrm{C}$ until further analysis.

b. Another sample of powdered leaf sample $(10.0 \mathrm{~g})$ was extracted with boiling water $(200.00 \mathrm{~mL})$. The water extract was filtered and stored at $-20^{\circ} \mathrm{C}$ until further analysis.

Preliminary phytochemical screening indicated, higher extraction yield and biological activity in the ethanolic extraction method compared to water extraction methods, hence the following assays and chromatographic analysis were conducted using only the ethanolic extract.

\section{Determination of Alpha-amylase inhibitory activity}

The concentration series of the ethanolic extract of cinnamon leaf $(390 \mu \mathrm{L}$ of $15.625,31.25,62.50,125$, 250 , and $500 \mu \mathrm{g} / \mathrm{mL}$ ) was mixed with alpha-amylase enzyme solution $(0.025 \mathrm{mg} / \mathrm{mL}, 10.0 \mu \mathrm{L})$ in sodium phosphate $(\mathrm{pH} 6.9,0.02 \mathrm{M})$ and incubated at $37{ }^{\circ} \mathrm{C}$ for 10 minutes. A starch solution $(0.5 \%, 100 \mu \mathrm{L})$ was added. The mixture was incubated at $37^{\circ} \mathrm{C}$ for 15 min. After incubation, Iodine solution $(5 \mathrm{mM} \mathrm{KI}$ and $\left.5 \mathrm{mM} \mathrm{I}_{2}\right)(100 \mu \mathrm{L})$ was added. Distilled water $(5.0$ $\mathrm{mL}$ ) was added and the absorbance was measured at $565 \mathrm{~nm}$. Control experiments were conducted using sodium phosphate buffer instead of the extract. The same procedure was followed for blank samples using sodium phosphate instead of an enzyme solution. Acarbose was used as the positive control. The following equation was used to evaluate the \% inhibition;

\section{$\%$ Inhibition $=[(\mathrm{B}-\mathrm{A})(\mathrm{D}-\mathrm{C}) /(\mathrm{B}-\mathrm{A})] \times 100$}

(A, B, C, D - Absorbance at $565 \mathrm{~nm}$ without leaf extract and with $\alpha$-amylase enzyme, Absorbance at $565 \mathrm{~nm}$ without leaf extract and $\alpha$-amylase enzyme, Absorbance at $565 \mathrm{~nm}$ with extract of leaf and $\alpha$ amylase enzyme, Absorbance at $565 \mathrm{~nm}$ with leaf extract and without $\alpha$-amylase enzyme, respectively)

\section{Determination of Alpha-glucosidase inhibitory activity}

Different concentrations of the ethanolic extract of cinnamon leaf $(50.0 \mu \mathrm{L}$ of $31.25,62.50,125,250$, $500,1000 \mu \mathrm{g} / \mathrm{mL}$ ) were mixed with alphaglucosidase solution $(1.0 \mathrm{U} / \mathrm{mL}, \quad 25.0 \mu \mathrm{L})$ in phosphate buffer $(0.1 \mathrm{M}, \mathrm{pH} 6.8)$ and incubated at 37 ${ }^{0} \mathrm{C}$ for $10 \mathrm{~min}$. p-nitrophenyl- $\alpha$-D-glucopyranoside substrate $(2.5 \mathrm{mM}, 25 \mu \mathrm{L})$ in phosphate buffer was added after pre-incubation. The solutions were incubated at $37^{\circ} \mathrm{C}$ for 10 minutes and the absorbance at $405 \mathrm{~nm}$ was measured using a UV spectrophotometer. Control experiments were conducted by replacing the extracts with sodium phosphate. The same procedure was followed for sample blanks using sodium phosphate instead of the enzyme solution. As the positive control acarbose was used. Using the following equation \% inhibition was calculated;

$\%$ Inhibition $=[(A-B)(C-D) /(A-B)] \times 100$

(A, B, C, D - Absorbance at $405 \mathrm{~nm}$ without extract and with alpha-glucosidase enzyme, Absorbance at $405 \mathrm{~nm}$ without extract and alpha-glucosidase enzyme, Absorbance at $405 \mathrm{~nm}$ with extract and alpha-glucosidase enzyme, Absorbance at $405 \mathrm{~nm}$ with extract and without alpha-glucosidase enzyme, respectively)

\section{Determination of total phenolic content}

The Folin Ciocalteu method modified by (Ranilla et al., 2010)was used to determine the total phenolic content.

The ethanolic extract of cinnamon leaf $(1.0 \mathrm{~mL})$ was mixed with ethanol $(95 \%, 1.0 \mathrm{~mL})$. Then distilled water $(5.0 \mathrm{~mL})$ and Folin Ciocalteu reagent $(50 \%, 0.5$ $\mathrm{mL})$ were added and mixed. After $5 \mathrm{~min}, \mathrm{Na}_{2} \mathrm{CO}_{3}$ $(5 \%, 1.0 \mathrm{~mL})$ was added. After incubation for 60 minutes, the absorbance at $725 \mathrm{~nm}$ was measured using Gallic acid as the reference compound.

\section{Determination of total flavonoid content}

The aluminium chloride method reported by (Yang et al, 2012) was used to determine the total condensed flavonoid content.

Each ethanolic extract of cinnamon leaf $(1.0 \mathrm{~mL})$ was swirled for 1 minute. Aluminium chloride (10\%, $100.00 \mu \mathrm{L})$, potassium acetate $(1.0 \mathrm{M}, 100.00 \mu \mathrm{L})$ and Methanol $(3.8 \mathrm{~mL})$ were added into it. The solution was incubated at $37^{\circ} \mathrm{C}$ for 40 minutes and the absorbance at $415 \mathrm{~nm}$ was measured. Quercetin was used as the reference compound.

\section{Determination of total proanthocyanidins content} To determine the total proanthocyanidins content, the procedure reported by (Rebaya et al., 2015) was used 


\section{Nimarsha Sonali Kamaradiwela Arachchige and Bimali Jayawardena}

with slight modifications.

The ethanolic extract of cinnamon leaf $(400.00 \mu \mathrm{L})$ was added to a solution of vanillin $(4 \%, 3.0 \mathrm{~mL})$ and concentrated hydrochloric acid $(1.5 \mathrm{~mL})$. The solution was incubated at $37^{\circ} \mathrm{C}$ for 15 minutes and the absorbance was measured at $500 \mathrm{~nm}$ using Catechin as the reference compound.

\section{Determination of antioxidant activity}

DPPH radical scavenging method by (Chatatikun and Chiabchalard, 2013) was used to determine the antioxidant activity with slight modifications.

Varying the concentrations of ethanolic extract of cinnamon leaf $(160.00 \mu \mathrm{L})$ and 2,2-diphenyl-2picrylhydrazyl hydrate (DPPH) $(0.25 \mathrm{mg} / \mathrm{mL}, 40.00$ $\mu \mathrm{L})$ were mixed in a 96 well microtiter plate. The solution was incubated in the dark for 15 minutes at $37^{\circ} \mathrm{C}$. The absorbance was measured at $517 \mathrm{~nm}$ with a UV spectrophotometer using Methanol as the blank. Ascorbic acid was used as the control.

Inhibition $(\%)=\left[\left(\mathrm{Abs}_{\text {control }}-\mathrm{Abs}\right.\right.$ sample $) / \mathrm{Abs}$ control $] \times \mathbf{1 0 0}$

Gas chromatographic-mass spectroscopic (GCMS) analysis

Volatile constituents of the ethanolic leaf extract were screened using a GC-MS instrument [Agilent 7890B GC equipped with Mass Selective Detector (MSD), and Agilent 5977B HP5 column (30.00 $\mathrm{m} \times$ $0.25 \mathrm{~mm} \times 0.25 \mu \mathrm{m})$ ], with quadrupole temperature at $150^{\circ} \mathrm{C}$, ion source temperature at $230^{\circ} \mathrm{C}$ and electronic ionization energy of $70 \mathrm{eV}$. The flow rate of the Helium carrier gas (mobile phase) was set at $1.0 \mathrm{~mL} / \mathrm{min}$. The injection volume was $1.0 \mu 1$ and the temperature program was set at a rate of $8{ }^{\circ} \mathrm{C} / \mathrm{min}$ from $40{ }^{\circ} \mathrm{C}$ to $250{ }^{\circ} \mathrm{C}$. The peaks of the ethanolic leaf extracts were identified using the software package installed on the GC-MS system (NIST MS library).

\section{High performance liquid chromatography (HPLC) analysis}

The chemical identity of the $C$. zeylanicum leaf extract was explored using a HPLC instrument. For the analysis, HPLC (Agilent Technologies 1260 Infinity II) with a reversed-phase C18 column and a UV Detector were used. As the mobile phase methanol, acetonitrile, and water mixture in a ratio of $35: 20: 45$ was pumped at a flow rate of $1.0 \mathrm{~mL} / \mathrm{min}$. Absorbance was recorded at $210 \mathrm{~nm}$. A $10.0 \mu \mathrm{L}$ sample was injected into the C18 column and the eluted fractions were collected for 30 minutes at $38^{\circ} \mathrm{C}$. Leaf extracts and standards were dissolved in methanol. The Retention times and spectra were compared with standards for identification and quantification.

\section{Statistical analysis}

Experimental data were analyzed by one-way analysis of variance (ANOVA) followed by Tukey's multiple comparison test and student's t- test using GraphPad Prism 8 (GraphPad Software, USA), where $\mathrm{p}<0.05$ was considered significant. All results are presented as mean \pm SEM $(n=3)$.

\section{Results}

Three methods of extraction using water and ethanol were carried out to determine the best method for extracting leaves of Sri Gemunu and Sri Wijaya Cinnamomum zeylanicum accessions. Each extraction yield was expressed as weight/weight percentage. According to the results (Table 1), the highest yield was observed in the ethanolic extraction of both accessions compared to the other methods. The Sri Wijaya accession showed a higher extraction yield in each method than the Sri Gemunu accession. Ethanolic extract was used for further assays, as it gave a considerable extraction yield for both accessions. The yield in the hot water extract was quite low for both accessions while the pressurized hot water extract was significantly low for Sri Gemunu accession.

Table-1: Extraction yield in different methods

\begin{tabular}{|l|c|c|}
\hline \multirow{2}{*}{ Extraction Method } & \multicolumn{2}{|c|}{ Extraction yield \% (w/w) } \\
\cline { 2 - 3 } & Sri Gemunu & Sri Wijaya \\
\hline Ethanolic extraction & $6.20 \pm 0.20$ & $9.90 \pm 0.67$ \\
\hline Hot water extraction & $0.70 \pm 0.06$ & $4.00 \pm 0.37$ \\
\hline $\begin{array}{l}\text { Pressurized hot water } \\
\text { Extraction }\end{array}$ & $1.0 \pm 0.12$ & $8.00 \pm 0.15$ \\
\hline
\end{tabular}

Alpha-amylase and Alpha-glucosidase inhibitory activities were determined using the ethanolic extract (Table 2). Usually lower the IC50 value, the higher the inhibition percentage which means higher the anti-diabetic properties. The $\mathrm{IC}_{50}$ value of the commercial inhibitor Acarbose for the alpha-amylase assay and that of Sri Gemunu were similar. $\alpha$ Glucosidase was strongly inhibited by Sri Gemunu leaf extract based on the $\mathrm{IC}_{50}$ value and in 


\section{Nimarsha Sonali Kamaradiwela Arachchige and Bimali Jayawardena}

comparison to acarbose. However, when comparing the $\mathrm{IC}_{50}$ value of acarbose for alpha-glucosidase inhibition, both Sri Gemunu and Sri Wijaya extracts showed strong alpha-glucosidase inhibitory potential.

Table-2: $\mathrm{IC}_{50}$ values for inhibition of $\alpha$-amylase and $\alpha$-glucosidase

\begin{tabular}{|l|c|c|}
\hline \multirow{2}{*}{ Sample } & \multicolumn{2}{|c|}{ IC $_{\mathbf{5 0}}$ value $^{\boldsymbol{a}}(\mathbf{m g} / \mathbf{m L})$} \\
\cline { 2 - 3 } & $\alpha$-amylase & $\alpha$-glucosidase \\
\hline Sri Gemunu & $0.0565 \pm 0.0013$ & $0.0347 \pm 0.0002$ \\
\hline Sri Wijaya & $0.1136 \pm 0.0011$ & $0.0884 \pm 0.0002$ \\
\hline Acarbose & $0.0469 \pm 0.0002$ & $1.3000 \pm 0.0500$ \\
\hline
\end{tabular}

a The sample concentration required for $50 \%$ inhibition of the $\alpha$-amylase enzyme and the $\alpha-$ glucosidase enzyme in $\mathrm{mg} / \mathrm{mL}$.

The total phenol content, total flavonoid content and proanthocyanidin content in ethanolic extracts of both varieties were determined using spectrophotometric methods. The results are depicted in Table 3. The findings unveiled that of the two accessions of Cinnamomum zeylanicum, Sri Gemunu accession was rich in the above phytochemicals compared to Sri Wijaya accession.

Table-3: Total phenolic compounds, flavonoids, and proanthocyanidins in cinnamon leaf extracts

\begin{tabular}{|c|c|c|c|}
\hline \multirow{2}{*}{$\begin{array}{c}\text { Leaf } \\
\text { accession }\end{array}$} & \multicolumn{3}{|c|}{ Phytochemical analysis } \\
\cline { 2 - 4 } & $\begin{array}{c}\text { Content of } \\
\text { Phenolics (mg } \\
\text { gallic acid } \\
\text { eq/g) })^{\mathbf{a}}\end{array}$ & $\begin{array}{c}\text { Content of } \\
\text { Flavonoids (mg } \\
\text { quercetin eq/g) }\end{array}$ & $\begin{array}{c}\text { Content of } \\
\text { Proanthocyanidins } \\
\text { (g catechin eq/g) }^{\mathbf{c}}\end{array}$ \\
\hline $\begin{array}{c}\text { Sri } \\
\text { Gemunu }\end{array}$ & $20.60 \pm 0.01$ & $72.02 \pm 0.02$ & $0.60 \pm 0.05$ \\
\hline Sri Wijaya & $6.07 \pm 0.01$ & $23.59 \pm 0.02$ & $0.15 \pm 0.05$ \\
\hline
\end{tabular}

${ }^{\mathrm{a}}$ Content of phenolics is expressed as $\mathrm{mg}$ of gallic acid equivalents per g dry matter.

b Content of flavonoids is expressed as $\mathrm{mg}$ of quercetin equivalents per $\mathrm{g}$ dry matter.

${ }^{c}$ Content of Proanthocyanidins is expressed as $g$ of Catechin equivalents per $\mathrm{g}$ dry matter.

Table-4:IC $\mathrm{IC}_{50}$ values for Antioxidant activity by DPPH assay in Cinnamomum zeylanicum leaves

\begin{tabular}{|l|c|}
\hline \multicolumn{1}{|c|}{ Leaf accession } & $\mathbf{I C}_{\mathbf{5 0}} \mathbf{v a l u e}^{\mathbf{a}}(\boldsymbol{\mu} \mathbf{g} / \mathbf{m L})$ \\
\hline Sri Gemunu & $69.60 \pm 5.48$ \\
\hline Sri Wijaya & $58.18 \pm 2.53$ \\
\hline Ascorbic acid & $7.33 \pm 0.14$ \\
\hline
\end{tabular}

${ }^{a}$ The sample concentration required to scavenge $50 \%$ of the DPPH radical in $\mu \mathrm{g} / \mathrm{mL}$.
The hydrogen donated by the antioxidants present in the extract reduced the absorbance of the DPPH radical due to the scavenging of the radical. The $\mathrm{IC}_{50}$ value calculated using dose-response curve for the DPPH radical scavenging activity of ethanolic extracts is given in Table 4. Sri Wijaya leaf extract gave a lower $\mathrm{IC}_{50}(58.18 \pm 2.53 \mu \mathrm{g} / \mathrm{mL})$ value compared to Sri Gemunu. Hence Sri Wijaya leaf extract has better DPPH radical scavenging activity out of the two accessions.

The major constituents present in ethanolic extracts of the two accessions are tabulated in Table 5. The peak area percentage is directly proportional to the constituent percentage in the leaf extract. In comparing the percentages of the constituents in the two accessions, Sri Gemunu had a higher percentage than in Sri Wijaya. However eugenol content was higher in Sri Wijaya accession.

Table-5: The chemical composition of ethanolic leaf extracts of Cinnamomum zeylanicum according to Gas Chromatographic analysis

\begin{tabular}{|l|c|c|}
\hline \multirow{2}{*}{\multicolumn{1}{|c}{ Identity of the compound }} & \multicolumn{2}{|c|}{$\begin{array}{c}\text { Percentage of the } \\
\text { compound (\%) }\end{array}$} \\
\cline { 2 - 3 } & $\begin{array}{c}\text { Sri Gemunu } \\
\text { accession }\end{array}$ & $\begin{array}{c}\text { Sri Wijaya } \\
\text { accession }\end{array}$ \\
\hline Cinnamaldehyde & 3.1497 & 1.0924 \\
\hline Eugenol & 76.678 & 78.2319 \\
\hline Palmitic acid & 1.6972 & 2.9191 \\
\hline Caryophyllene & 3.2195 & 2.3902 \\
\hline Xanthumin & 2.1567 & Not found \\
\hline Dodecanoic acid & 1.2916 & Not found \\
\hline $\begin{array}{l}\text { 4-Hydroxy-2- } \\
\text { methoxycinnamaldehyde }\end{array}$ & 2.8491 & 1.8744 \\
\hline Benzyl benzoate & 1.4749 & 1.1568 \\
\hline Benzaldehyde & 3.0639 & 2.9725 \\
\hline L-Linalool & Not found & 2.0398 \\
\hline $\begin{array}{l}\text { Phenol, 2,2'-methylenebis[6-(1,1- } \\
\text { dimethylethyl)-4-methyl-(CAS) }\end{array}$ & 3.5888 & 5.5027 \\
\hline
\end{tabular}

The concentration in $\mathrm{mg} / \mathrm{g}$ of each compound present in ethanolic extracts of the two accession analyzed using HPLC is shown in Table 6. The results from the HPLC chromatography also confirmed that eugenol content in Sri Wijaya accession is higher than Sri Gemunu accession. However, cinnamaldehyde and cinnamic acid contents were higher in Sri Gemunu than in Sri Wijaya. 
Table-6: Amount of constituents in Cinnamomum zeylanicum leaf extract according to HPLC chromatographic analysis

\begin{tabular}{|c|c|c|c|}
\hline $\begin{array}{c}\text { Leaf } \\
\text { accession }\end{array}$ & $\begin{array}{c}\text { Eugenol } \\
\text { amount } \\
(\mathbf{m g} / \mathbf{g})\end{array}$ & $\begin{array}{c}\text { Cinnamaldehyd } \\
\text { e amount }(\mathbf{m g} / \mathbf{g})\end{array}$ & $\begin{array}{c}\text { Cinnamic acid } \\
\text { amount }(\mathbf{m g} / \mathbf{g})\end{array}$ \\
\hline Sri Gemunu & $51.30 \pm 0.01$ & $67.50 \pm 0.02$ & $58.80 \pm 0.10$ \\
\hline Sri Wijaya & $62.50 \pm 0.01$ & $58.50 \pm 0.02$ & $41.80 \pm 0.10$ \\
\hline
\end{tabular}

\section{Discussion}

Inhibition of both hydrolytic enzymes alpha-amylase and alpha-glucosidase is considered as a treatment option in treating diabetes mellitus. The inhibition of these two enzymes helps to lower the postprandial glucose level (Adisakwattana et al., 2011). Hence scientists are interested in searching for therapeutic drugs with enzyme inhibitory activity and with fewer side effects from herbal plants.

In extracting plant metabolites, the method of extraction and solvent used determines the extraction yield and the composition of the extract. Ethanol is a polar solvent that can facilitate the extraction of polar compounds present plants such as phenols and flavonoids. Phenol and flavonoids are responsible for the biological activity observed in plant extracts. Hence in comparing the three extraction methods, ethanolic extraction showed the highest extraction yield. The prolonged extraction time and heating in the Soxhlet could be the reason for the enhanced efficiency of the method. Use of ethanol for the extraction of polyphenols is safe as it is non-toxic for human consumption compared to most solvents (Husain et al., 2018).

This study showed both Sri Gemunu and Sri Wijaya leaf accessions of Cinnamomum zeylanicum possess inhibitory activity against both alpha-amylase and alpha-glucosidase enzymes. The $\mathrm{IC}_{50}$ values are comparable to the commercial inhibitor Acarbose.

The presence of several phytochemicals such as phenolics, flavonoids, and proanthocyanidins might be responsible for this inhibitory activity of the cinnamon leaf extract (Ranilla et al., 2010).

Phenolics are the secondary metabolites in plants that possess anti-oxidant activity (Muhammad and Dewettinck, 2017). Oxidative stress is responsible for chronic diseases such as diabetes. Hence, it was recently discovered that natural antioxidants have a potential therapeutic effect in controlling type 2 diabetes mellitus by reducing oxidative stress. Apart from serving as inhibitors of the above dietary enzymes the plant extracts also could reduce oxidative stress and thereby control diabetes. Previous studies have reported that the ability of cinnamon to control diabetes is due to its enzyme inhibitory and antioxidant activities. These studies depicted that certain polyphenolic compounds which are soluble in water play a significant role in the antidiabetic potential of cinnamon(Jayaprakasha and Rao, 2011). Studies have found that there is a close relationship between the flavonoids present in cinnamon and its ability to prevent diabetes through its anti-oxidant potential (Prasad et al.,2009).

According to previous studies, proanthocyanidins are the major anti-diabetic component present in cinnamon (Jiao et al., 2013). Administration of tannin imparts the ability to inhibit the digestive enzyme alpha-amylase (Lee et al.,2007). Thus tannins/proanthocyanidins exhibit anti-oxidative and anti-diabetic properties.

Both GC-MS and HPLC chromatographic results showed that Sri Wijaya is rich in Eugenol content. According to previous studies, eugenol content has a direct relationship with anti-oxidant activity. Thus these results comply with the previous findings (Schmidt et al., 2006). Results indicate that both new accessions of leaf possess a considerable amount of phenolics, flavonoids, proanthocyanidins, and antioxidants. However further phytochemical characterization on these compounds is essential for potential applications in the treatment of diabetes mellitus.

There was a variation in the percentage of the components present in the two accessions based on GC/MS data. The GC mass spectrum of components in Sri Gemunu and Sri Wijaya ethanolic extracts were compared with the mass spectrum of the components in the database (NIST library). The peak area percentage and compound names were ascertained using the database. Cinnamaldehyde, Benzaldehyde, Caryophyllene, and Xanthumin were rich in Sri Gemunu accession while Eugenol, Llinalool, and Palmitic acid were abundant in Sri Wijaya accession.

Both HPLC chromatograms illustrated high content of Eugenol than Cinnamaldehyde and Cinnamic acid. The wavelength $210 \mathrm{~nm}$ was selected as the suitable wavelength for chromatographic detection of all the analytes because it provided the best signal to noise background ratio and it was close to $\lambda \max _{\text {of }}$ 
maximum components.

\section{Conclusion}

It can be concluded that both accessions of Cinnamomum zeylanicum leaf exhibit anti-diabetic properties in a synergistic manner due to the antiamylase, anti-glucosidase, and anti-oxidant activities. Results of phytochemical assays suggest that Sri Gemunu accession is rich in phenolic content, flavonoid content, and proanthocyanidin content than Sri Wijaya accession. Further comprehensive investigations on these extracts are required to evaluate the relationship with inhibitory activities. The high sensitivity of GC-MS and HPLC techniques were helpful in the characterization of bioactive compounds present in Cinnamomum zeylanicum leaf. It can be concluded that the Sri Gemunu commercial Cinnamomum zeylanicum leaf accession has better anti-diabetic properties than the Sri Wijaya Cinnamomum zeylanicum leaf accession.

\section{Acknowledgement}

The authors graciously acknowledge the financial support from the National Science Foundation (SP/CIN/2016/03) and Cinnamon Research Station, Palolpititya, Thihagoda, Sri Lanka to carry out this work.

Disclaimer: None.

Conflict of Interest: None.

Source of Funding: This work was supported by the National Science Foundation grant, funded by the Republic of Sri Lanka (Grant Number: SP/CIN/2016/03).

\section{References}

Adisakwattana S, Lerdsuwankij O, Poputtachai U, Minipun A and Suparpprom C, 2011. Inhibitory Activity of Cinnamon Bark Species and their Combination Effect with Acarbose against Intestinal $\alpha$-glucosidase and Pancreatic $\alpha$ amylase.Plant Foods Hum. Nutr. 66(2): 143-148.

Apostolidis E and Lee CM, 2010. In vitro potential of Ascophyllum nodosum phenolic antioxidantmediated $\alpha$-glucosidase and $\alpha$-amylase inhibition. J. Food Sci. 75(3): 97-102.

Arachchige SPG, Abeysekera WPKM and
Ratnasooriya WD, 2017. Antiamylase, Anticholinesterases, Antiglycation, and Glycation Reversing Potential of Bark and Leaf of Ceylon Cinnamon (Cinnamomum zeylanicum Blume) in Vitro.Evidence-based Complement. Altern. Med. 2017: 1-13.

Ariyarathne HBMA, Weerasuriya SN and Senarath WTPSK, 2018. Comparison of morphological and chemical characteristics of two selected accessions and six wild species of genus Cinnamomum SCHAEFF. Sri Lankan J. Biol.3(1): 11.

Azad R, Senanayake G, Kumara W, Ranawaka R, PushpaKumara D and Geekiyanage S, 2015. Morphological variation within progeny and deviations from mother plant reveal the allele richness in Cinnamomum verum germ- plasm: a case study from deiyandara, matara collection at the early vegetative stage.Trop. Agric. Res. Ext. 18(4): 163-167.

Chatatikun M and Chiabchalard A, 2013. Phytochemical screening and free radical scavenging activities of orange baby carrot and carrot (Daucus carota Linn.) root crude extracts.J. Chem. Pharm. Res. 5(4): 97-102.

Fenn Mavis L and Koppedrayer K, 2008. Research Article Research Article.J. Glob. Buddhism. 9(1): 45-79.

Husain I, Ahmad R, Chandra A, Tasleem S and Shukla Y, 2018. Phytochemical characterization and biological activity evaluation of ethanolic extract of Cinnamomum zeylanicum.J. Ethnopharmacol. 219: 110-116.

Jayaprakasha GK and Rao LJM, 2011. Chemistry, biogenesis, and biological activities of Cinnamomum zeylanicum.Crit. Rev. Food Sci. Nutr. 51(6): 547-562.

Jiao L, Zhang X, Huang L, Gong H, Cheng B, Sun Y and Huang K, 2013. Proanthocyanidins are the major anti-diabetic components of cinnamon water extract. Food Chem. Toxicol. 56:398-405.

Kazeem MI, Adamson JO and Ogunwande IA, 2013. Modes of inhibition of $\alpha$-amylase and $\alpha$ glucosidase by aqueous extract of Morinda lucida benth leaf.Biomed Res. Int. 2013: 1-6.

Lee YA, Eun JC, Tanaka T and Yokozawa T, 2007. Inhibitory activities of proanthocyanidins from persimmon against oxidative stress and digestive enzymes related to diabetes. J. Nutr. Sci. Vitaminol.53(3): 287-292.

Liyanage $\mathrm{T}$, Madhujith $\mathrm{T}$ and Wijesinghe KGG, 


\section{Nimarsha Sonali Kamaradiwela Arachchige and Bimali Jayawardena}

2017. Comparative study on major chemical constituents in volatile oil of true cinnamon (Cinnamomum verum Presl. syn. C. zeylanicum Blum.) and five wild cinnamon species grown in Sri Lanka. Trop. Agric. Res. 28(3): 270.

Mendis Abeysekera WPK, Arachchige SPG, Abeysekera WKSM, Ratnasooriya WD and Indeewari Medawatta HMU, 2019. Antioxidant and Glycemic Regulatory Properties Potential of Different Maturity Stages of Leaf of Ceylon Cinnamon ( Cinnamomum zeylanicum Blume) In Vitro . Evidence-based Complement. Altern. Med. 2019: 1-10.

Muhammad DRA and Dewettinck K, 2017. Cinnamon and its derivatives as potential ingredient in functional food.Int. J. Food Prop., 20(2), 2237 2263.

Prasad K, Yang B, Dong X, Jiang G, Zhang H, Xie $\mathrm{H}$ and Jiang $\mathrm{Y}, 2009$. Flavonoid contents and antioxidant activities from Cinnamomum species. Innov. Food Sci. Emerg. Technol. 10(4): $627-$ 632.

Ranilla LG, Kwon YI, Apostolidis E and Shetty K, 2010. Phenolic compounds, antioxidant activity and in vitro inhibitory potential against key enzymes relevant for hyperglycemia and hypertension of commonly used medicinal plants, herbs and spices in Latin America. Bioresour. Technol. 101(12): 4676-4689.

Rebaya A, Belghith SI, Baghdikian B, Leddet VM and Mabrouki F, 2015. Total Phenolic , Total Flavonoid , Tannin Content, and Antioxidant
Capacity of Halimium halimifolium (Cistaceae).J. Appl. Pharm. Sci. 5(01): 52-57.

Sangal A, 2011. Role of cinnamon as beneficial antidiabetic food adjunct.Adv. Appl. Sci. Res. 2(4): 440-450.

Schmidt E, Jirovetz L, Buchbauer G, Eller GA, Stoilova I, Krastanov A and Geissler M, 2006. Composition and antioxidant activities of the essential oil of cinnamon (Cinnamomum zeylanicum blume) leaves from Sri Lanka.J. Essent. Oil-Bearing Plants. 9(2): 170-182.

Tulini L, Souza VB, Echalar-barrientos MA, Thomazini M, Pallone EMJA and Favarotrindade CS, 2016. Development of solid lipid microparticles loaded with a proanthocyanidinrich cinnamon extract (Cinnamomum zeylanicum): Potential for increasing antioxidant content in functional foods for diabetic population. Food Res. Int. 85: 10-18.

Yang C, Li R and Chuang L, 2012. Antioxidant Activity of Various Parts of Cinnamomum cassia Extracted with Different Extraction Methods. Molecules. 17(6): 7294-7304.

\section{Contribution of Authors}

Arachchige NSK: Performed experiments, data collection $\&$ analysis and manuscript write up Jayawardena B: Planned and designed research experiments and gave final approval of article 